\title{
Focus The Historic New Orleans on \\ Collection
}

Libraries

\author{
By Pamela D. Arceneaux
}

\section{A stop to make in the French}

\section{Quarter}

$\mathbf{T}$ he Historic New Orleans Collection (HNOC), a privately endowed independent museum research center is located in the heart of the French Quarter at 533 Royal St. It was established in 1966 by the late General and Mrs. L. Kemper Williams, private collectors of Louisiana material, to maintain and expand their collections and make them available to the public through research facilities and exhibitions. Open to the pulblic since 1974, the research collections, comprising approximately 14,000 volumes, 9,000 pamphlets, 5,700 linear feet of documents and manuscripts, a microfilm collection. and approximately 300,000 photographs. prints, drawings and

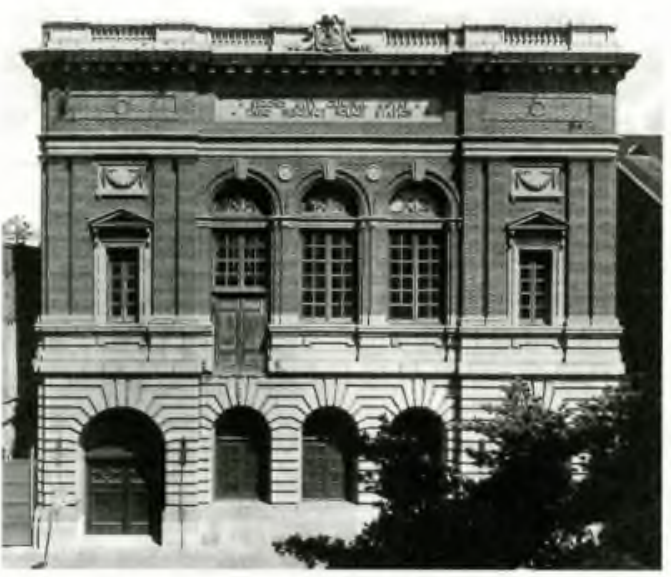

A lavishly restored court and police station is now home to the Historic New Orleans Collection's Williams Research Center.

photo by Jan white Brantley since 1978. history and culture through the research center, museum exhibitions, and publications; and maintaining the Williams residence as a house museum reflecting the Williams's French Quarter lifestyle in the mid-20th century. The Historic New Orleans Collection has been accredited by the American Association of Museums

In cooperation with the Louisiana Historical Association, the HNOC annually awards the Kemper and Leila Williams Prize to the best published work in Louisiana history. The awards are presented every March at the annual conference of the Louisiana Historical Association. The Collection also periodically awards Williams Research Fellowships for postchoctoral and dissertation projects.

The Williams Gallery, located in the 1792 Merieult House, is free to the public and highlights various aspaintings, reflect aspects of the history and culture of Gulf South, Louisiana, and New Orleans.

Inhabiting a complex of seven 18 th- and 19th-century buildings, the Collection employs a full-time staff of 40 engaged in a three-part mission: preserving and acquiring books, manuscripts, and visual materials that document the history and culture of the immediate region; promoting the study and appreciation of local pects of the Collection's holdings through everchanging exhibitions. For a nominal charge, visitors may view a series of ten permanent history galleries illustrating the development of the Crescent City or view the Williams residence, a late 19th-century "hidden house" remodeled in the 1940s to accommodate the fine antiques and gracious lifestyle of the General and his wife, Leila. Both tours are interpreted by experienced docents. 
The Collection's Publications Division produces The Historic New Orleans Collection Quarterly, exhibition catalogs, and many books of local interest, including a popular guidebook series entitled Preservation Guides. These publications, Louisiana prints, unusual gift items, and estate jewelry are available for purchase from the Shop at the Collection.

\section{Services}

The three research divisions service (Library, Curatorial, and Manuscripts) approximately 7,800 researchers annually by telephone, mail, or in person to the Collection. Researchers range from visitors with a casual curiosity about the New Orleans area to grade-school students working on their first research project to worldrenowned scholars, novelists, and filmmakers. Materials do not circulate, and stack areas are closed to the public. Depending upon the current workload, reading room staff may undertake limited research for indivicluals unable to conduct their own research. Visiting researchers are interviewed by the staff concerning their topics and goals and have access to the Collection's automated catalogs and other finding aids. The Collection has mounted a homepage on the Internet through the World Wide Web. The Web site provides up-to-date information on holdings, galleries and exhibitions, the Williams residence, the Shop at the Collection, Collection publications, and the annual Williams Prize competition. The Collection's URL is http://www.hnoc.org/

\section{Visits and tours}

The Historic New Orleans Collection is open Tuesclay-Saturday (except holidays) at 10:00 a.m. The Williams Gallery closes at 4:45 p.m.; the Williams Research Center closes at 4:30 p.m. Research guicles are available upon request.

Tours of the history galleries and Williams residence are $\$ 2$ each. Reservations required for groups of eight or more and for school groups.

For further information, please contact:

The Historic New Orleans Collection, 533 Royal Street, New Orleans, Louisianá, 70130; (504) 523-4662.

Williams Research Center, 410 Chartres Street, New Orleans, Louisiana, 70130: (504) 598-7171.

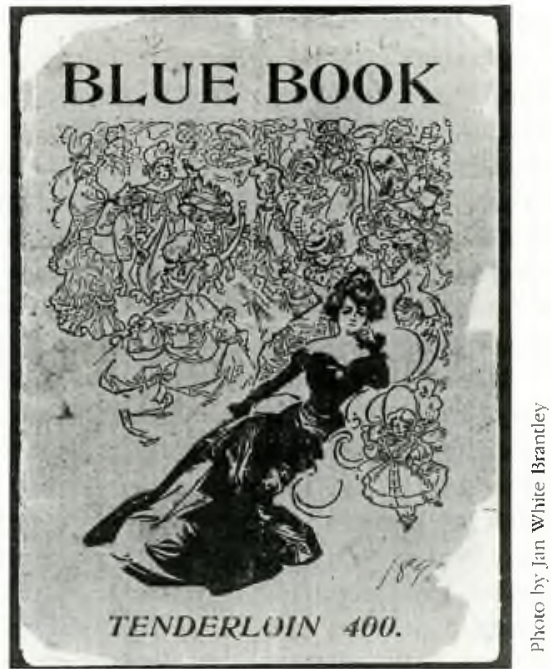

This guide to New Orleans' red-light district can be found at the Williams Research Center.

\section{The Collections}

Among the "gems" of the Collection are 37,000 photographs and negatives of the American photographer, Clarence John Laughlin, and the approximately 1,800 drawings made mostly for Harper's Weekly by 19th-century illustrator, Alfred R. Waud. The Vieux Carré Survey, an archive of some 160 binders, contains information about individual pieces of property in the French Quarter and is accessible by current street address. The first printed account of Louisiana, Abbé Hennepin's Description de la Louisiane (1683); Het Groole Tafereel der Ducasabid (The Great Mirror of Folly. 1720), satirical cartoons, essalys, and verse describing John Law's Mississippi schemes; and Les Cenelles (1845), the earliest volume of published poetry by free men of color in the United States, are among the Collection's most noteworthy items.

Manuscript collections include a variety of letters, diaries, land tenure records, financial and legal papers, as well as extensive microfilmed documents from the Archives Nationales de France, the Archivo General de Indies, and the National Archives. New Orleans newspapers from 1803 to the present form a large portion of the microfilm collection.

\section{New Williams Research Center facilitates service}

The HNOC is at the threshold of a new era in its history. Until recently, researchers were re- 
quired to visit three separate reading rooms, shoehorned into three different buildings in the Royal Street complex in order to access materials. Named in honor of the Collection's founders, the new Williams Research Center, located at 410 Chartres St. (about two blocks away from the Royal Street headquarters) opened on January 20,1996, with a series of lectures during the day and a black-tie gala that evening.

The building, a lavish restoration of the Second City Criminal Court and Third District Police Station, boasts a spacious reading room on the second floor. This new reading room eliminates the need for researchers to be escorted from one research area to another. Books, manuscripts, microfilm, photographs, maps, and a wealth of other primary and secondary resources may be consulted in one setting with, perhaps, the assistance of only one staff member.

As visitors enter the Williams Research Center, they are directed to a sweeping stairway or to public elevators, which take them to the second-floor reading room with its huge arched windows, mezzanine stacks, handmade library tables, and vintage chandeliers. Fanning out from the centerpiece reading room are storage vaults, staff workspaces, and equipment housing.

The new Williams Research Center's home is in the Beaux Arts municipal building, designed by prolific architect Edgar Angelo Christy (1881-1959). When it was built in 1915, it replaced a row of decrepit, 19th-century shops. Hired as a New Orleans city architect in 1904, Christy was largely noted for his firehouse designs. Between 1911 and 1940, he served as the supervising architect of the Orleans Parish School board and was responsible for design ing some of the city's earliest modern public schools; many are still in use, a testament to their sturdy construction. Bought by the state of Louisiana in 1957, the old court and police station was vacant and exposed to the elements for nearly 20 years when the HNOC acquired it in 1993

The sensitive restoration and adaptive reuse of this fine, though long-neglected building not only provides a more convenient facility for researchers, more capacity for storage of existing collections and future acquisitions, and office space for research and technical staff, but it also reflects the HNOC's continued faith in the vitality of the French Quarter.

\title{
HHOICE Web Review Issue!
} CHOICE continues to bring you the hest...

\author{
$\checkmark$ Reviews of some 200 research-related Web sites \\ $\checkmark$ Concise, informative evaluations \\ $\checkmark$ Features, including Librarians on the \\ Internet and Internet/Web books
}

Order extras for staff, faculty, students, and home. $\$ 20 /$ copy (inc.s\&h) Quantity discounts available.

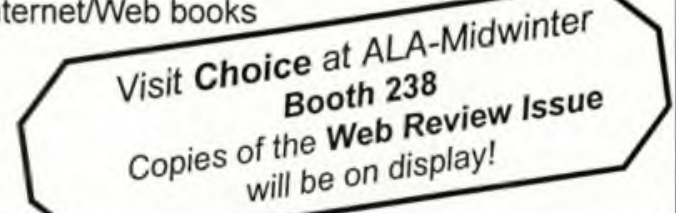

CHOICE Web Issue Sales 100 Riverview Center Middletown, CT 06457

Fax: 860-704-0465. Phone: 860-347-6933 x33. choicemag@ala-choice.org visit us at www.ala.org/acrl/choice 


\section{Document suppliers come and go but CISTI is here to stay}

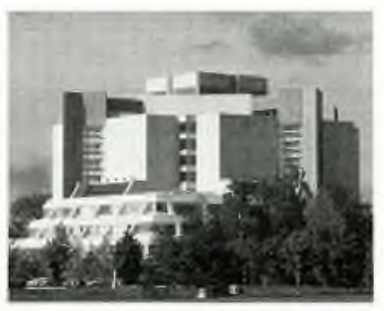

1 Reliability

Our dedicated staff and fully automated system supply articles, reports and conference proceedings from our in-house collection.

\section{Speed}

Most orders are processed in one day, while our urgent service delivers in only 4 hours.

\section{Flexibility}

We offer 12 options for ordering (OCLC, DOCLINE, Web and others) and fax, Ariel, ftp, or print delivery.

\section{Economy}

Articles can cost as low as $\$ 8$ each (plus actual copyright charges). Prices are even lower for high volumes.

\section{Client Service}

Our client service team will impress you with the fast and meticulous way they handle your concerns.

For a free Guide to CISTI's Document Delivery Services or to register contact CISTI at 1-800-668-1222, cisti.info@nrc.ca or http://www.nrc.ca/cisti

CELEBRATING 75 YEARS OF SERVICE IN 1999 